Article

\title{
Light Energy Partitioning and Photoprotection in an Exotic Species (Salix Psammophila) Grown in a Semi-Arid Area of Northwestern China
}

\author{
Yini Han ${ }^{1,2}$, Juying $\mathrm{Wu}^{2}$, Yun Tian ${ }^{3, *}$, Tianshan Zha ${ }^{1,3}{ }^{3}$, Xin Jia ${ }^{3}$, Charles P.-A. Bourque ${ }^{4}$, \\ Yajuan $\mathrm{Wu}^{3}$, Yujie Bai ${ }^{3}$, Jingyong $\mathrm{Ma}^{3}$ and Mingyan Zhang ${ }^{3}$ \\ 1 Key Laboratory of Soil and Water Conservation and Desertification Combating, Ministry of Education, \\ Beijing Forestry University, Beijing 100083, China; han-yini@hotmail.com (Y.H.); \\ tianshanzha@bjfu.edu.cn (T.Z.) \\ 2 Beijing Research \& Development Center for Grass and Environment, Beijing Academy of Agriculture and \\ Forestry Sciences, Beijing 100097, China; wujuying@grass-env.com \\ 3 Yanchi Research Station, School of Soil and Water conservation, Beijing Forestry University, Beijing 100083, \\ China; xinjia@bjfu.edu.cn (X.J.); yajuanwu2015@sina.com (Y.W.); bloweer@bjfu.edu.cn (Y.B.); \\ majy2015@bjfu.edu.cn (J.M.); guiyibamoxi@outlook.com (M.Z.) \\ 4 Faculty of Forestry and Environmental Management, 28 Dineen Drive, University of New Brunswick, \\ Fredericton, NB E3B 6C2, Canada; cbourque@unb.ca \\ * Correspondence: tianyun@bjfu.edu.cn; Tel.: +86-1571-296-9958
}

Received: 3 April 2018; Accepted: 4 June 2018; Published: 9 June 2018

\begin{abstract}
Thermal dissipation of excess excitation energy is an important photoprotective mechanism that plants have evolved to cope with surplus illumination. However, light-energy-partitioning dynamics in an exotic sand-dune willow (Salix psammophila) commonly used in restoring and/or stabilizing sand lands in northwestern China is largely unknown. In this study, chlorophyll fluorescence (ChlF) of photosystem II (PSII) was continuously monitored in situ in Salix psammophila to investigate plant acclimation processes driven by excessive solar radiation and extreme air temperatures $\left(T_{a}\right)$. As part of a heat-regulation mechanism, energy partitioning is shown to vary with prevailing environmental conditions. In this investigation, energy absorbed during periods of moderate photosynthetically active radiation $\left(P A R<1200 \mu \mathrm{moL} \cdot \mathrm{m}^{-2} \cdot \mathrm{s}^{-1}\right)$ was largely allocated towards photochemistry $\left(\Phi_{\mathrm{PSII}}\right)$ with nominal amounts to thermal dissipation through reversible thermal dissipation $\left(\Phi_{\mathrm{NPQr}}\right)$. In extremely high solar radiation $\left(P A R>1500 \mu \mathrm{moL} \cdot \mathrm{m}^{-2} \cdot \mathrm{s}^{-1}\right)$ or in a cold temperature $\left(T_{a}<0{ }^{\circ} \mathrm{C}\right)$, more energy was dissipated by way of non-regulated thermal energy $\left(\Phi_{\mathrm{f}, \mathrm{D}}\right)$ and sustained thermal dissipation $\left(\Phi_{\mathrm{NPQs}}\right)$, leading to non-reversible photoinhibition or photodamage. This was mainly as a result of the low utilization and high absorption of light energy by PSII under cold conditions and physiologically-induced vulnerability. It was concluded that Salix psammophila had a clear tolerance to high temperatures and moderate solar radiation, but tended to be more vulnerable to high solar radiation and cold temperature. Based on species sensitivity to extreme environmental conditions, practical application and extension of Salix psammophila for land-restoration purposes should be approached cautiously, especially in high-latitude or high-altitude desert ecosystems commonly affected by events of high solar radiation and cold temperature.
\end{abstract}

Keywords: Chlorophyll fluorescence; environmental stress; semi-arid; energy partitioning; Salix psammophila 


\section{Introduction}

Chlorophyll fluorescence (ChlF) has been one of the most dependable and preferred methods of determining physiological responses in plants growing in stressed environments [1,2]. Pulse-amplitude modulated (PAM) fluorescence provides a rapid and non-intrusive means of estimating ChlF-associated parameters in investigating vegetation response to stressful conditions [3-6]. The maximal quantum yield of photosystem II (PSII) photochemistry $\left(\mathrm{F}_{v} / \mathrm{F}_{m}\right)$ derived from PAM-fluorometry is regularly used as an indicator of plant photosynthetic performance and health status $[7,8]$. Low $\mathrm{F}_{v} / \mathrm{F}_{m}$ values arise when plants are subject to biotic and/or abiotic stresses, pointing to possible damage to the PSII reaction centers $(\mathrm{RC})$ [5,9-11].

Light energy that plants absorb often exceeds the plants' needs for photosynthesis in the field, particularly in arid- and semi-arid areas of the world. Of numerous photoprotective mechanisms, the non-photochemical quenching coefficient (NPQ) of excess light energy within the light-harvesting antennae of PSII (LHCII) is believed to be the most effective. As a ratio of regulated and non-regulated heat dissipation, the increase in NPQ indicates elevated photoprotection in response to excessive sunlight $[12,13]$. Indeed, even though the majority of excess light energy is safely dissipated through the NPQ pathway, photoinhibition is still inevitable, leading to photodamage as a result of the overproduction of reactive oxygen species (ROS) [14,15].

Monitoring energy partitioning with the ChlF-technique is a well-tested method of examining acclimation processes in stressed vegetation [16]. Light energy absorbed by the light-harvesting complex in PSII (LHCII) is dispersed along three principal consumption pathways [17], i.e., (i) energy transfer to the photochemical portion of PSII ( $\left.\Phi_{\text {PSII }}\right)$, and (ii) through non-regulated and regulated thermal energy loss ( $\Phi_{\mathrm{f}, \mathrm{D}}$ and $\Phi_{\mathrm{NPQ}}$, respectively). Allocation of light energy to the three energy consumption pathways yields $\Phi_{\mathrm{PSII}}+\Phi_{\mathrm{NPQ}}+\Phi_{\mathrm{f}, \mathrm{D}}=1$. The three pathways are competitive, but function at a level of trade-off. Plants maintain equilibrium through the relative balance of energy consumption. Under certain environmental stress, the optimal regulation of maximal $\Phi_{\text {PSII }}$ is maintained under high $\Phi_{\mathrm{NPQ}}: \Phi_{\mathrm{f}, \mathrm{D}}$ ratios (NPQ) $[18,19]$. ChlF-associated parameter $\Phi_{\mathrm{NPQ}}$ is an important indicator of the actinic (photosynthetic) protective process. Energy dissipation associated with the xanthophyll cycle $\left(\Phi_{\mathrm{NPQ}}\right)$ increases under moderate environmental stress, which plays an important role in protecting the photosynthetic apparatus from damage under strong daylight conditions [20]. As an indicator of photodamage, the retention of $\Phi_{\mathrm{f}, \mathrm{D}}$ is thought to be associated with a decrease in the photoprotective protein (PsbS), which reveals the inability of plants to protect themselves against damage from surplus illumination.

For improved understanding of seasonal acclimation in plants to environmental stress, two photoprotective thermal dissipation strategies $\left(\Phi_{\mathrm{NPQ}}\right)$ were examined [21]. They concern (i) the rapid reversible dissipation $\left(\Delta \mathrm{pH}\right.$-dependent and PsbS-controlled; $\Phi_{\mathrm{NPQr}}$ ) associated with photoprotection during warm, summer conditions on timescales of seconds to minutes [22]; and (ii) sustained thermal dissipation $\left(\Delta \mathrm{pH}\right.$-independent; $\left.\Phi_{\mathrm{NPQs}}\right)$ in several evergreens and over-wintering plants under unfavorable growing conditions. Sustained thermal dissipation persists over time and is maintained in non-daylight conditions under adverse environmental conditions, which leads to a reduction in $\mathrm{F}_{v} / \mathrm{F}_{m}$. This process is believed to be regulated by the sustained retention of zeaxanthin and antheraxanthin, as well as by the structural reorganization of protein complexes in the thylakoid membrane over protracted timescales [1,21,23-25].

Extreme weather events are anticipated to occur more often under global climatic change [26-28]. Plants develop many morphological features and physiological strategies to acclimate to environmental conditions [29-32]. However, many plants may not be able to acclimate to the fluctuating environment at the same rate as the climate evolves $[8,15,33,34]$. Dryland plant species are especially sensitive to climate change and understanding how these plants may cope with widely fluctuating environments is of special concern [35]. Most studies conducted on plants in semi-arid areas focus on the indirect impacts of soil water deficits on light energy partitioning and/or photosynthetic capacity [36-38]. Intense solar radiation accompanied by high- or low-temperature stress serves as a direct threat 
to PSII RC by affecting the light-harvesting complexes and enzyme activity. High temperatures adversely affect physiological processes that can reduce plant growth and survival in a number of ways $[32,39]$. PSII is the site that damage is sustained from high temperatures $>45{ }^{\circ} \mathrm{C}$. Partial and reversible photoinhibition to PSII can result from moderate heat stress, i.e., air temperatures between 35-42 ${ }^{\circ} \mathrm{C}$ [40-42]. While being exposed to the same high temperature treatment, relative inhibition varies significantly among plant species [43]. Rapidly reversible downregulation of PSII quantum efficiency by increased $\Phi_{\mathrm{NPQ}}$ plays an important photoprotective role in leaves. This process involves the conversion of xanthophyll pigments and the development of a thylakoid proton electrochemical potential difference, and is clearly a crucial protective measure against the more harmful impacts of photodamage [44].

Salix psammophila C. Wang et C.Y. Yang, a non-native species, has been widely used in the construction of sand-breaks in the Mu Us desert sand lands since the 1980's. The species was introduced to the $\mathrm{Mu}$ Us desert from eastern Inner Mongolia (China) for afforestation due to its rapid growth and resistance to partial burial. However, as a mesophytic plant, Salix psammophila prefers to grow in moderate environmental conditions, including in moderate sunlight, temperature, and soil water availability. Dead branches and physical decay in the species (with an average lifespan of about 20 years) were regularly observed throughout the study area $[45,46]$. We hypothesized that Salix psammophila has a limited capacity to acclimate to extreme (warm and cold) temperatures and excessive incident solar radiation common to the Mu Us desert.

The objective of this study was to: (i) examine the diurnal and seasonal dynamics of energy partitioning in environmentally-stressed plants through continuous measurement of $\Phi_{\mathrm{PSII}}, \Phi_{\mathrm{f}, \mathrm{D}}$, and $\Phi_{\mathrm{NPQ}}$, as key functional indicators of plant response; and (ii) explore species-specific acclimation strategies to anomalous temperatures and solar radiation intensities. The study has the potential to provide an improved characterization of Salix psammophila's response to changing climatic conditions.

\section{Materials and Methods}

\subsection{Study Site}

The study was carried out at the Yanchi Research Station $\left(37^{\circ} 42^{\prime} \mathrm{N}, 107^{\circ} 13^{\prime} \mathrm{E} ; 1530 \mathrm{~m}\right.$ a.s.l. $)$ of Beijing Forestry University, Ningxia province, along the southern edge of the Mu Us sand lands, northwestern China. The site is located in the mid-temperate zone and is characterized by a semi-arid continental monsoon climate. The mean annual temperature is approximately $8.1{ }^{\circ} \mathrm{C}$ (based on 1954-2004 data) and the frost-free season lasts on average for about 165 days [47,48]. The vegetation in the area consists of a mixture of deciduous shrub species, including Artemisia ordosica Krasch, Salix psammophila, Hedysarum mongolicum Turez, and Hedysarum scoparium Fisch. et Mey.

\subsection{Long-Term Monitoring of ChlF and Hydrometeorological Variables}

Chlorophyll fluorescence of Salix psammophila was monitored in situ with a MONITORING-PAM Multi-Channel Chlorophyll Fluorometer (Walz, Effeltrich, Germany) from 15 April to 13 October 2012. The MONI-PAM system is equipped with up to seven cylindrical-shaped, robust, and weather-resistant measuring heads (MONI-HEAD/485) recording PAM fluorescence, ambient PAR, and temperature. A portion of healthy sun leaf of the current year was affixed to the MONI-HEAD's leaf clip consisting of two aluminum frames $(35 \times 25 \mathrm{~mm})$. Three shrubs, representing three replicates, were monitored concurrently. The MONI-HEADs emitter-detector unit was secured to an iron stand to keep the unit stable in moderate wind speeds and was positioned to prevent self-shading. The leaf in the MONI-HEAD's leaf clip was replaced every two weeks to minimize the impact of leaf injury on ChlF measurements. Modulated blue LED lights of different intensities were used to measure the fluorescence emitted from a leaf sample. A saturating pulse of $3500 \mu \mathrm{moL} \cdot \mathrm{m}^{-2} \cdot \mathrm{s}^{-1}$ was supplied every ten minutes with a pulse duration of $<1 \mathrm{~s}$ for obtaining a reading of maximum fluorescence yield in the light-adapted state $\left(\right.$ or $\left.\mathrm{F}_{m}{ }^{\prime}\right)$. Actinic light $\left(1500 \mu \mathrm{moL} \cdot \mathrm{m}^{-2} \cdot \mathrm{s}^{-1}\right)$ was supplied to obtain the 
actual fluorescence yield ( or $\mathrm{F}_{t}$ ). The measuring light was switched off between every two consecutive measurements. ChlF-associated parameters $\mathrm{F}_{t}$ and $\mathrm{F}_{m}{ }^{\prime}$ were automatically recorded for each pulse by the PAM system. Prior-dawn (3:00-4:00) maximum ChlF was estimated as the maximum ChlF in the dark-adapted state $\left(\mathrm{F}_{m}\right)$, and the minimum $\mathrm{F}_{t}$ at night was estimated as $\mathrm{F}_{0}$ [49].

Photosynthetically active radiation $(P A R)$ and air temperature $\left(T_{a}\right)$ were recorded by the PAM system, together with corresponding ChlF-associated co-variates. Vapor pressure deficit (VPD) was calculated from $T_{a}$ and relative humidity $(R H)$, i.e., $V P D=0.611 \exp \left[17.27 T_{a} /\left(T_{a}+237.3\right)\right] \times$ (1-RH/100) [50], where $R H$ was measured with a thermohygrometer (HMP155A, Vaisala, Helsinki, Finland). Soil water content $(S W C)$ at a $0.7 \mathrm{~m}$ depth were measured with ECH2O-5TE sensors (Decagon Devices, Pullman, WA, USA). All hydrometeorological variables were measured every $10 \mathrm{~s}$ and then averaged or summed to generate 30-min values before being stored in data loggers (CR3000, Campbell Scientific Inc., Logan, UT, USA).

\subsection{ChlF-Parameter Calculation}

Seven ChlF-associated parameters were calculated for this analysis. Calculations were based on Equations (1)-(7) listed in Table 1. ChlF-associated parameters $\mathrm{F}_{o}$ and $\mathrm{F}_{m}$ are the minimum and maximum fluorescence measured at night and just prior to sunrise, respectively. Parameters $\mathrm{F}_{o}$ and $F_{m}$ were estimated nightly over the duration of the experiment. Parameter $F_{m R}$ was estimated from $\mathrm{F}_{m}$ when the photochemistry yield was greatest $[49,51]$. The degree of stress in Salix psammophila was quantified using five classes, i.e., no stress (with $\left.\mathrm{F}_{v} / \mathrm{F}_{m}>0.75\right)$, minor stress $(0.70-0.74)$, fair stress (0.65-0.69), moderate stress (0.60-0.65), and severe stress $(<0.59)$.

Table 1. Process yields and ChlF-associated yield equations.

\begin{tabular}{cccc}
\hline Process Yield & Equation & No. & Equation Source \\
\hline $\begin{array}{c}\text { Maximal quantum yield of PSII } \\
\text { photochemistry }\end{array}$ & $\mathrm{F}_{\mathrm{v}} / \mathrm{F}_{m}=\frac{\mathrm{F}_{m}-\mathrm{F}_{0}}{\mathrm{~F}_{m}}$ & 1 & {$[49]$} \\
$\begin{array}{c}\text { Actual quantum yield of PSII } \\
\text { photochemistry }\end{array}$ & $\Phi_{\mathrm{PSII}}=\frac{\mathrm{F}_{m} \prime}{\mathrm{F}_{m} \prime}$ & 2 & {$[5,9,17,52]$} \\
$\begin{array}{c}\text { Non-regulated thermal energy } \\
\text { loss }\end{array}$ & $\Phi_{\mathrm{f}, \mathrm{D}}=\frac{\mathrm{F}_{t}}{\mathrm{~F}_{m} \prime}$ & 3 & {$[17]$} \\
$\begin{array}{c}\text { Regulated thermal energy loss } \\
\text { Sustained thermal dissipation } \\
\text { Rapidly reversible thermal } \\
\text { dissipation }\end{array}$ & $\Phi_{\mathrm{NPQ}}=\frac{\mathrm{F}_{t}}{\mathrm{~F}_{m} \prime}-\frac{\mathrm{F}_{t}}{\mathrm{~F}_{m R}}$ & 4 & {$[49,51]$} \\
$\begin{array}{c}\Phi_{\mathrm{NPQs}}=\frac{\mathrm{F}_{t}}{\mathrm{~F}_{m}}-\frac{\mathrm{F}_{t}}{\mathrm{~F}_{m R}} \\
\text { Non-photochemical quenching } \\
\text { coefficient }\end{array}$ & $\Phi_{\mathrm{NPQr}}=\frac{\mathrm{F}_{t}}{\mathrm{~F}_{m} \prime}-\frac{\mathrm{F}_{t}}{\mathrm{~F}_{m}}$ & 6 & {$[3]$} \\
\hline
\end{tabular}

\subsection{Statistical Analyses}

Raw data of three replicate measurements were processed using the batch-file feature of the WinControl-3 software (pre-installed on the data logger). Chlorophyll fluorescence values were screened using limit checking. Half-hourly values of $\mathrm{F}_{t}<\mathrm{F}_{m}{ }^{\prime}$ (non-dimensional) were considered abnormal and were removed from the dataset. ChlF-data during rainy days with totals $>5 \mathrm{~mm}$ were removed. All analyses were performed with the SPSS v. 20.0 software package (SPSS, Chicago, IL, USA). Student $t$-tests were used to test the statistical significance of ChlF-associated parameters between summer and growing-season data. One-way analysis of variance (ANOVA) was conducted on seasonal variation in hydrometeorological variables (PAR and $T_{a}$ ) and ChlF-parameters (i.e., $\Phi_{\mathrm{NPQr}}$ and $\left.\Phi_{\mathrm{NPQs}}\right)$. Non-linear regressions were performed between $\mathrm{F}_{v} / \mathrm{F}_{m}$ and the environmental variables, i.e., maximum $P A R$, averaged $T_{a}, S W C$, and $V P D$. Normality and homogeneity of variance were verified using Levene's test. Statistical significance was identified at a significance level of 0.05. 


\section{Results}

\subsection{Environmental Dynamics}

There were periods of intense solar radiation and high temperature differences between daytime and nighttime periods (Figure 1), which are typical in semi-arid areas of northwestern China. Cold temperatures accompanied high $P A R$ in spring and autumn, and high temperatures and high $P A R$ in summer. Most months had a high midday $P A R>1200 \mu \mathrm{moL} \cdot \mathrm{m}^{-2} \cdot \mathrm{s}^{-1}$, with the exception of October $\left(P A R=1121 \mu \mathrm{moL} \cdot \mathrm{m}^{-2} \cdot \mathrm{s}^{-1}\right)$, particularly on May 2 with $P A R=1610 \mu \mathrm{moL} \cdot \mathrm{m}^{-2} \cdot \mathrm{s}^{-1}$, with a daily mean of $18.7-682.8 \mu \mathrm{moL} \cdot \mathrm{m}^{-2} \cdot \mathrm{s}^{-1}$ (Figure 2a). Daily mean $T_{a}$ ranged between $2.8-31.5^{\circ} \mathrm{C}$ (Figure $2 \mathrm{~b}$ ). The seasonal pattern of $V P D$ followed that of $T_{a}$, with a daily mean $V P D$ ranging from $0.15-1.92 \mathrm{kPa}$ (Figure 1c). Daily SWC ranged from $0.06-0.15 \mathrm{~m}^{3} \cdot \mathrm{m}^{-3}$ with two rapid increases in 30 June and 4 September, reaching a level of about $0.15 \mathrm{~m}^{3} \cdot \mathrm{m}^{-3}$ each time.

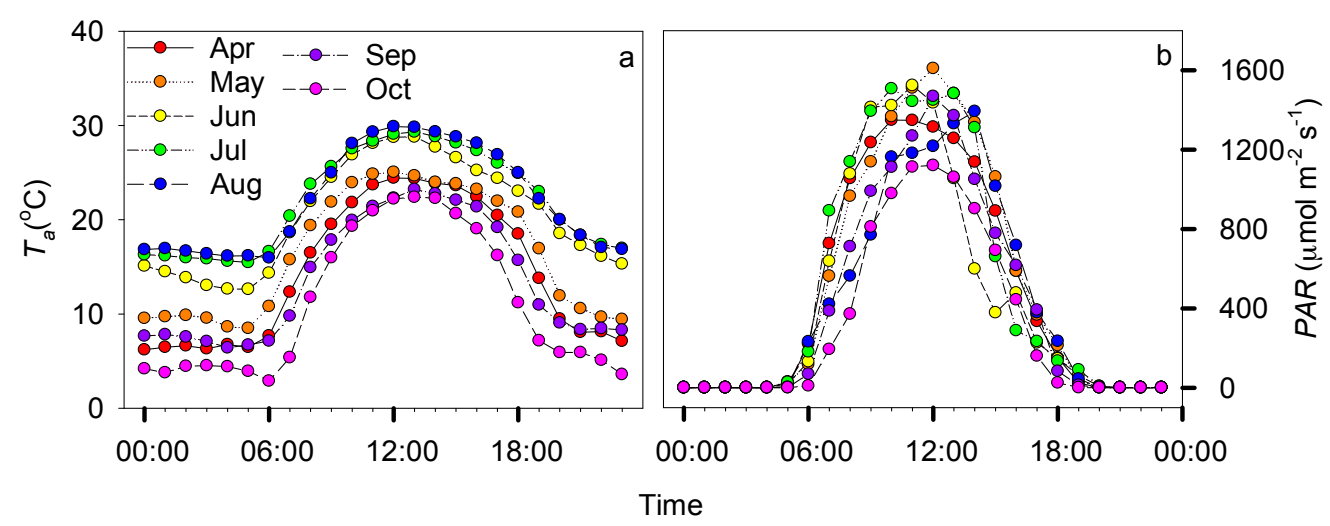

Figure 1. Monthly mean diurnal cycle of air temperature $\left(T_{a},(\mathbf{a})\right)$ and photosynthetically active radiation $(P A R,(\mathbf{b}))$ during the growing season (April-October) of 2012. 

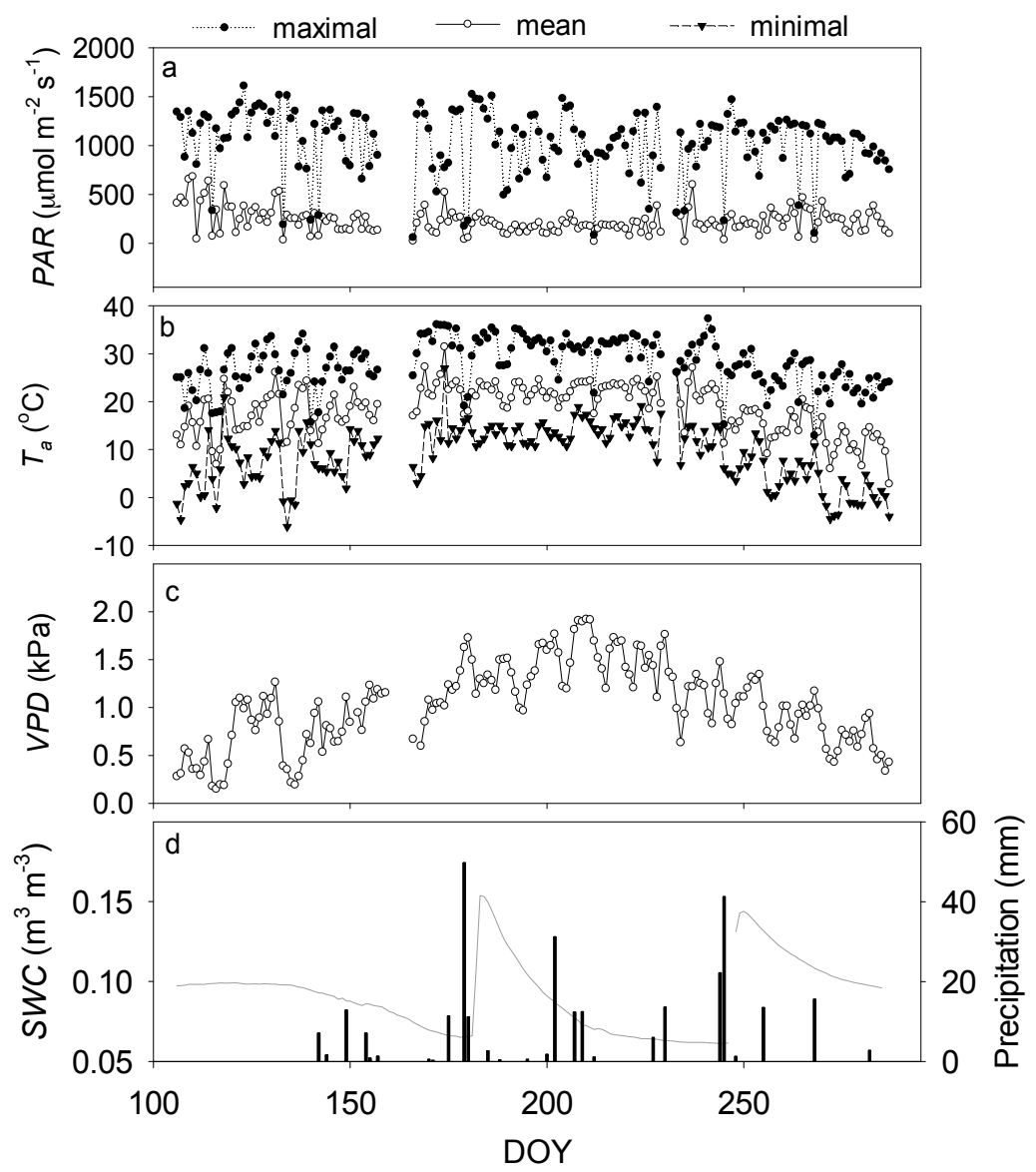

Figure 2. Seasonal variation in maximum, minimum, and mean daily photosynthetically active radiation $(P A R,(\mathbf{a}))$ and air temperature $\left(T_{a},(\mathbf{b})\right)$, daily mean vapor pressure deficit $(V P D,(\mathbf{c}))$, and daily mean soil water content at $0.7-\mathrm{m}$ depth $(S W C,(\mathbf{d})$; grey line) and daily precipitation ((d); column) from 15 April to 13 October 2012. Breaks in the SWC timeseries overlap periods of missing data. Here, spring refers to DOY (day of year) 106-152, summer DOY 153-244, and autumn DOY 245-287.

\subsection{Seasonal and Diurnal Dynamics in Energy Partitioning Components}

Diurnally, $\Phi_{\text {PSII }}$ exhibited a bell-shaped curve (Figure 3a), being highest at night $\left(\Phi_{\text {PSII }}>0.7\right)$ irrespective of season, and lowest $(<0.7)$ during daytime conditions, with the lowest value occurring between 10:00-13:00 LST (Local Standard Time), when PAR was highest (Figures 1 and 3). By contrast, $\Phi_{\mathrm{NPQ}}$ increased from morning, peaking at noon, when radiation was highest (Figure 3c). ChlF-associated parameter $\Phi_{\mathrm{f}, \mathrm{D}}$ changed marginally compared to $\Phi_{\mathrm{PSII}}$, with diurnal fluctuations ranging in between $0.13-0.28$ (Figure $3 b$ ). The non-photochemical quenching coefficient (NPQ) had a similar diurnal pattern to that of $\Phi_{\mathrm{NPQ}}$ (Figure 3d). 

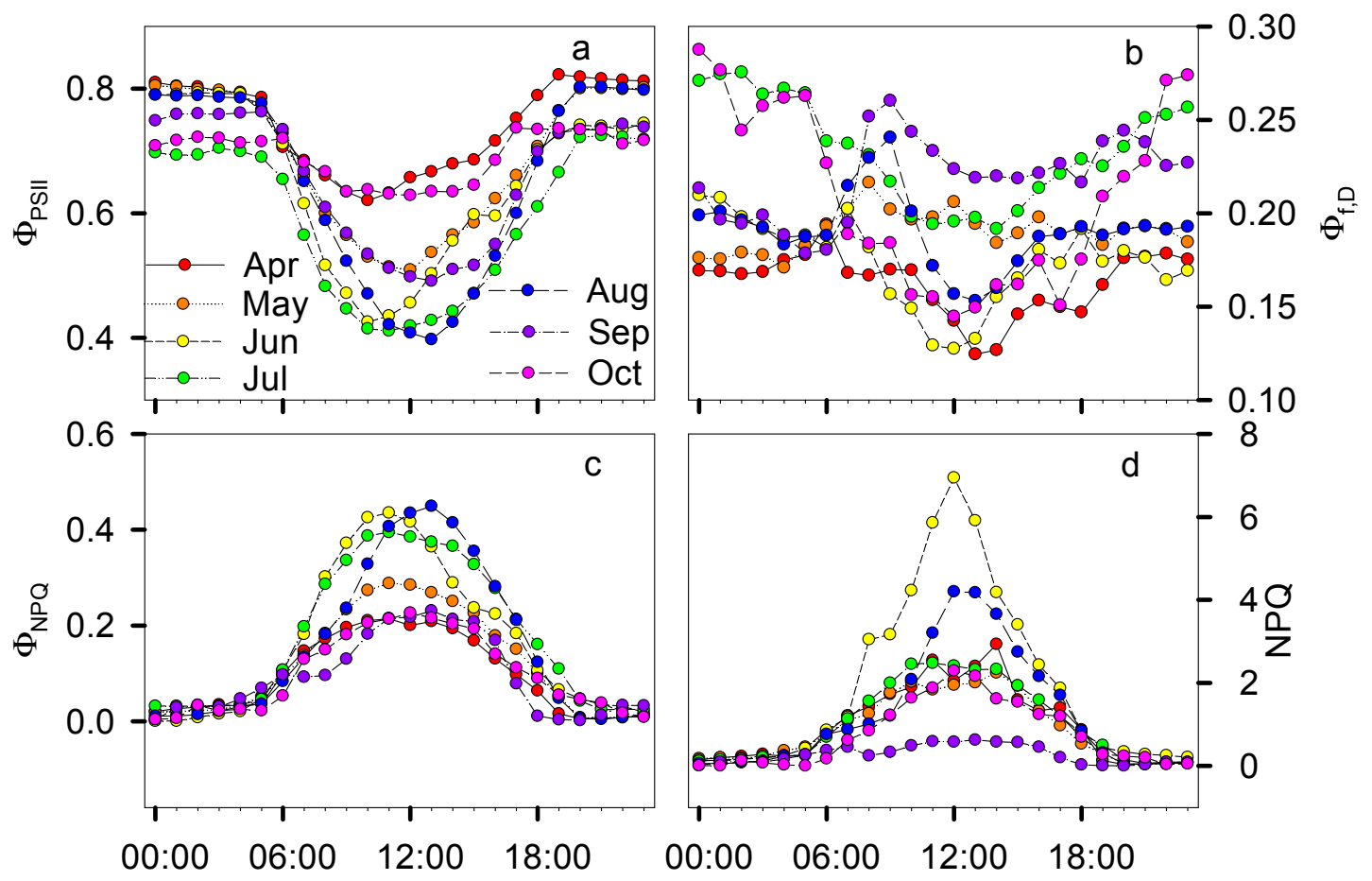

Time(hour)

Figure 3. Monthly mean diurnal cycle of energy partitioning in Salix psammophila during the growing season (April-October) of 2012, including actual quantum yield of PSII photochemistry ( $\Phi_{\mathrm{PSII}},(\mathbf{a})$ ), non-regulated energy loss $\left(\Phi_{\mathrm{f}, \mathrm{D}},(\mathbf{b})\right)$, regulated thermal energy loss $\left(\Phi_{\mathrm{NPQ}},(\mathbf{c})\right)$, and non-photochemical quenching coefficient (NPQ, or Stern-Volmer quenching, (d)).

There were clear seasonal patterns in energy partitioning, i.e., $\Phi_{\mathrm{PSII}}, \Phi_{\mathrm{NPQ}}$, and $\Phi_{\mathrm{f}, \mathrm{D}}$ (Figure 3), with $\Phi_{\mathrm{PSII}}$ being highest during the cold-temperature seasons (i.e., spring and autumn) and the daily mean ranging between 0.4-0.8. ChlF-parameter $\Phi_{\mathrm{NPQ}}$ demonstrated a contrasting temporal pattern. The highest daily mean $\Phi_{\mathrm{f}, \mathrm{D}}$ was observed in September, followed closely by $\Phi_{\mathrm{f}, \mathrm{D}}$-values in July and October. Lowest night values of $\Phi_{\mathrm{PSII}}$ were found to occur during the same three months.

\subsection{Non-Photochemical Quenching in Response to Solar Radation Stress}

Figure 4 illustrates energy partitioning with respect to $\Phi_{\mathrm{PSII}}, \Phi_{\mathrm{f}, \mathrm{D}}, \Phi_{\mathrm{NPQ}}$, and NPQ as a function of PAR during the growing season (open symbols) and during summer (close symbols), respectively. The photosynthetic capacity, denoted by $\Phi_{\mathrm{PSII}}$, decreased as PAR increased. Salix psammophila demonstrated a high quenching rate when $P A R<300 \mu \mathrm{moL} \cdot \mathrm{m}^{-2} \cdot \mathrm{s}^{-1}$ (Figure 4a). Accordingly, photoprotection, denoted by $\Phi_{\mathrm{NPQ}}$, rapidly increased as solar radiation increased (Figure $4 \mathrm{~b}$ ). Seasonally, $\Phi_{\mathrm{NPQ}}$ was apparently higher in summer days (June-August). While passive thermal dissipation (i.e., $\Phi_{\mathrm{f}, \mathrm{D}}$ ) remained fairly stable when $P A R<1200 \mu \mathrm{moL} \cdot \mathrm{m}^{-2} \cdot \mathrm{s}^{-1}$, averaging about 0.24 and 0.18 during the growing season and summer periods, respectively. However, $\Phi_{\mathrm{f}, \mathrm{D}}$ rapidly increased when $P A R>1200 \mu \mathrm{moL} \cdot \mathrm{m}^{-2} \cdot \mathrm{s}^{-1}$, peaking at 0.3 (Figure $4 \mathrm{c}$ ). Parameter NPQ continued to increase with increasing PAR, until PAR reached $1200 \mu \mathrm{moL} \cdot \mathrm{m}^{-2} \cdot \mathrm{s}^{-1}$. During the summer, Salix psammophila exhibited a decreased photochemical efficiency and relatively constant passive thermal dissipation under moderate illumination, with strengthened thermal dissipation by way of $\Phi_{\mathrm{NPQ}}$ (solid symbols, Figure 4).

ChlF-parameters $\Phi_{\mathrm{NPQr}}$ and $\Phi_{\mathrm{NPQs}}$ demonstrated varying sensitivity and patterns to solar radiation in different months (Figure 5). $\Phi_{\mathrm{NPQr}}$ accounted for a larger proportion of $\Phi_{\mathrm{NPQ}}$ and it was generally more responsive to solar radiation than $\Phi_{\mathrm{NPQ}}$, increasing with increasing PAR. 
The reduction in $\Phi_{\mathrm{NPQr}}$ in response to environmental stress varied seasonally, with $\Phi_{\mathrm{NPQr}}$ decreasing and gradually approaching $\Phi_{\mathrm{NPQs}}$ at the beginning and end of the growing season (Figure 5).

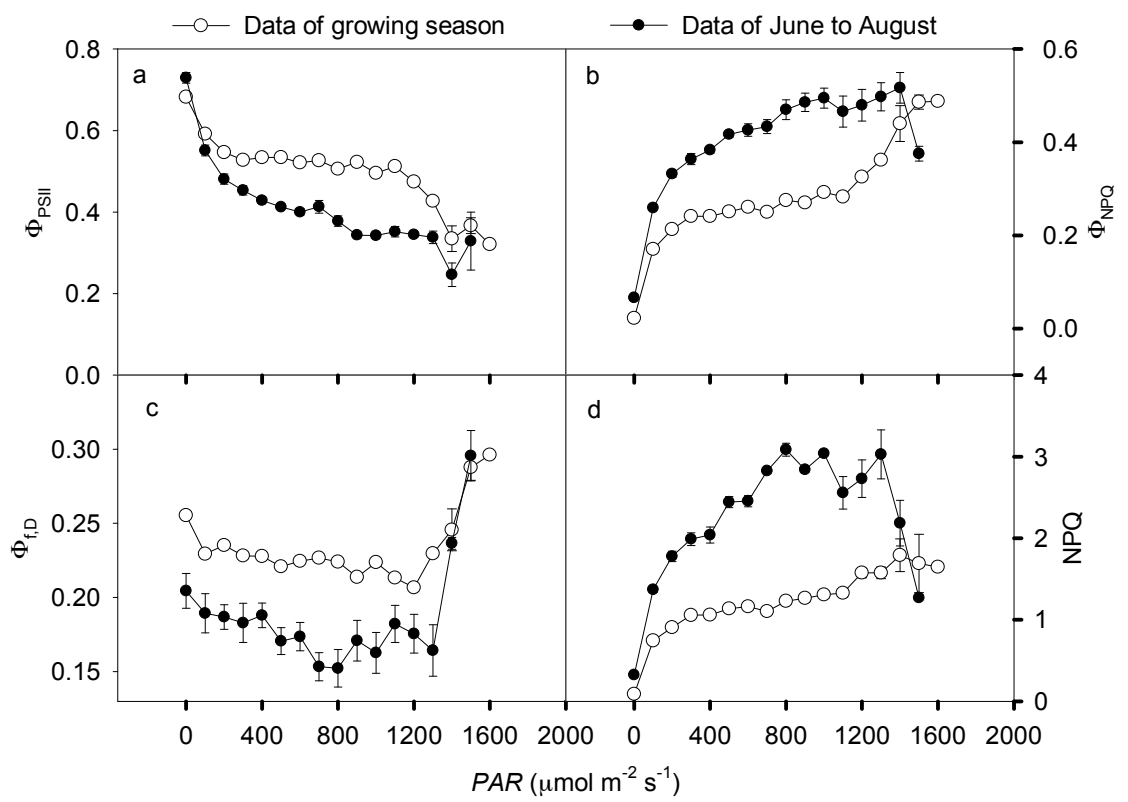

Figure 4. Actual quantum yield of PSII photochemistry $\left(\Phi_{\mathrm{PSII}},(\mathbf{a})\right)$, regulated thermal energy loss $\left(\Phi_{\mathrm{NPQ}},(\mathbf{b})\right)$, non-regulated energy loss $\left(\Phi_{\mathrm{f}, \mathrm{D}},(\mathbf{c})\right)$, and non-photochemical quenching coefficient (NPQ, Stern-Volmer quenching, (d)) in Salix psammophila as a function of photosynthetically active radiation $(P A R)$ during the growing season of 2012. Data points of energy partitioning and NPQ represent bin-averaged values. Here, the bins are set at $100 \mu \mathrm{moL} \cdot \mathrm{m}^{-2} \cdot \mathrm{s}^{-1}$ increments of $P A R$ with a minimal sample size of six. The open and closed circles represent averages of data collected over the entire growing season and summer period, respectively. The error bars denote standard error.

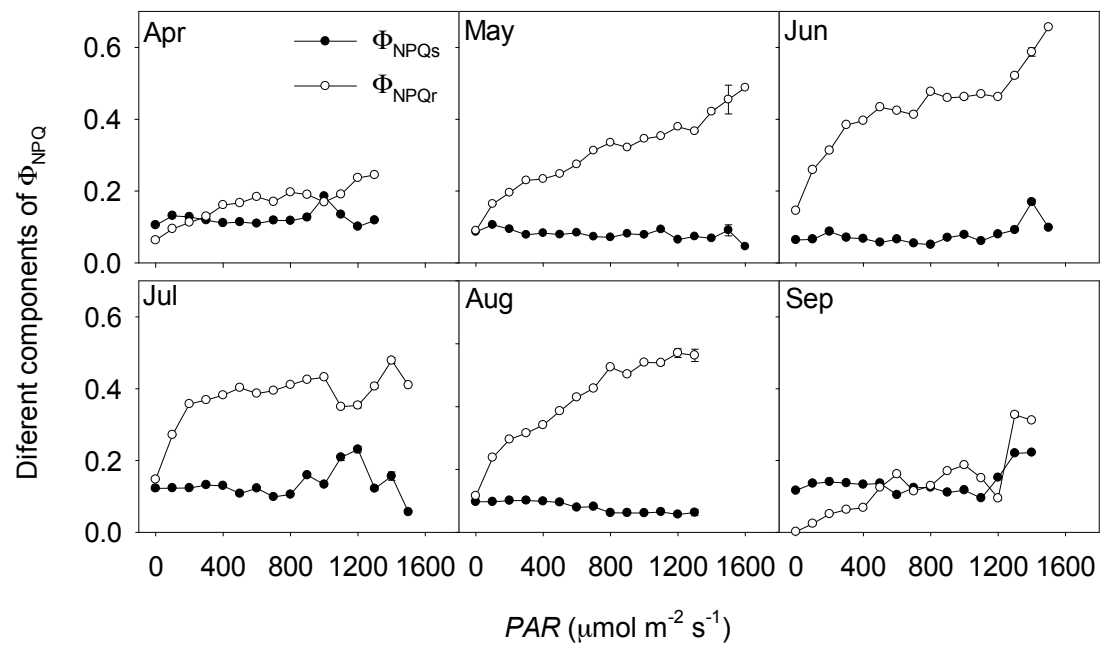

Figure 5. Seasonal variation in sustained and rapidly reversible thermal dissipation (i.e., $\Phi_{\mathrm{NPQs}}$ and $\left.\Phi_{\mathrm{NPQr}}\right)$ in Salix psammophila as a function of photosynthetically active radiation (PAR). Data points of $\Phi_{\mathrm{NPQs}}$ and $\Phi_{\mathrm{NPQr}}$ represent bin-averaged values. Here, the bins are set at $100 \mu \mathrm{moL} \cdot \mathrm{m}^{-2} \cdot \mathrm{s}^{-1}$ increments of $P A R$ with a minimal sample size of six. The error bars denote standard error.

\subsection{Non-Photochemical Quenching in Response to Temperature Stress}

In order to eliminate the effect of the diurnal dynamic, the effects of temperature on energy partitioning $\left(\Phi_{\mathrm{PSII}}, \Phi_{\mathrm{NPQ}}, \Phi_{\mathrm{f}, \mathrm{D}}\right)$ and on two regulated thermal energy loss components $\left(\Phi_{\mathrm{NPQ}}\right.$, 
$\left.\Phi_{\mathrm{NPQs}}\right)$ were analyzed based on values at night $\left(P A R<5 \mu \mathrm{moL} \cdot \mathrm{m}^{-2} \cdot \mathrm{s}^{-1}\right.$, Figure $\left.6 \mathrm{a}-\mathrm{c}\right)$ and at noon $\left(P A R \geq 1000 \mu \mathrm{moL} \cdot \mathrm{m}^{-2} \cdot \mathrm{s}^{-1}\right.$, Figure $\left.6 \mathrm{~b}-\mathrm{d}\right)$, respectively. ChlF-parameter $\Phi_{\text {PSII }}$ was positively correlated to $T_{a}$ at night, with an obvious depression when $T_{a} \leq 0{ }^{\circ} \mathrm{C}$. Meanwhile, $\Phi_{\mathrm{NPQs}}$ stayed above $\Phi_{\mathrm{NPQr}}$ at night, and showed a negative relationship with temperature when $T_{a}>0{ }^{\circ} \mathrm{C}$. Under the extreme cold condition $\left(T_{a} \leq 0{ }^{\circ} \mathrm{C}\right)$, the excess energy partitioning dissipated by increasing $\Phi_{\mathrm{f}, \mathrm{D}}$. At noon, $\Phi_{\mathrm{PSII}}$ remained constant and equal when $T_{a}<30{ }^{\circ} \mathrm{C}$. Obvious depression of $\Phi_{\mathrm{PSII}}$ corresponding with a high degree of regulated thermal energy loss occurred under a high temperature $\left(T_{a}>30{ }^{\circ} \mathrm{C}\right)$, whereas $\Phi_{\mathrm{f}, \mathrm{D}}$ remained constant with increasing temperature. There was an inverse pattern of the two components of regulated energy loss where $\Phi_{\mathrm{NPQr}}$ played a dominant role in regulated thermal dissipation when $T_{a}>20^{\circ} \mathrm{C}$, with a positive regulation with increasing temperature.

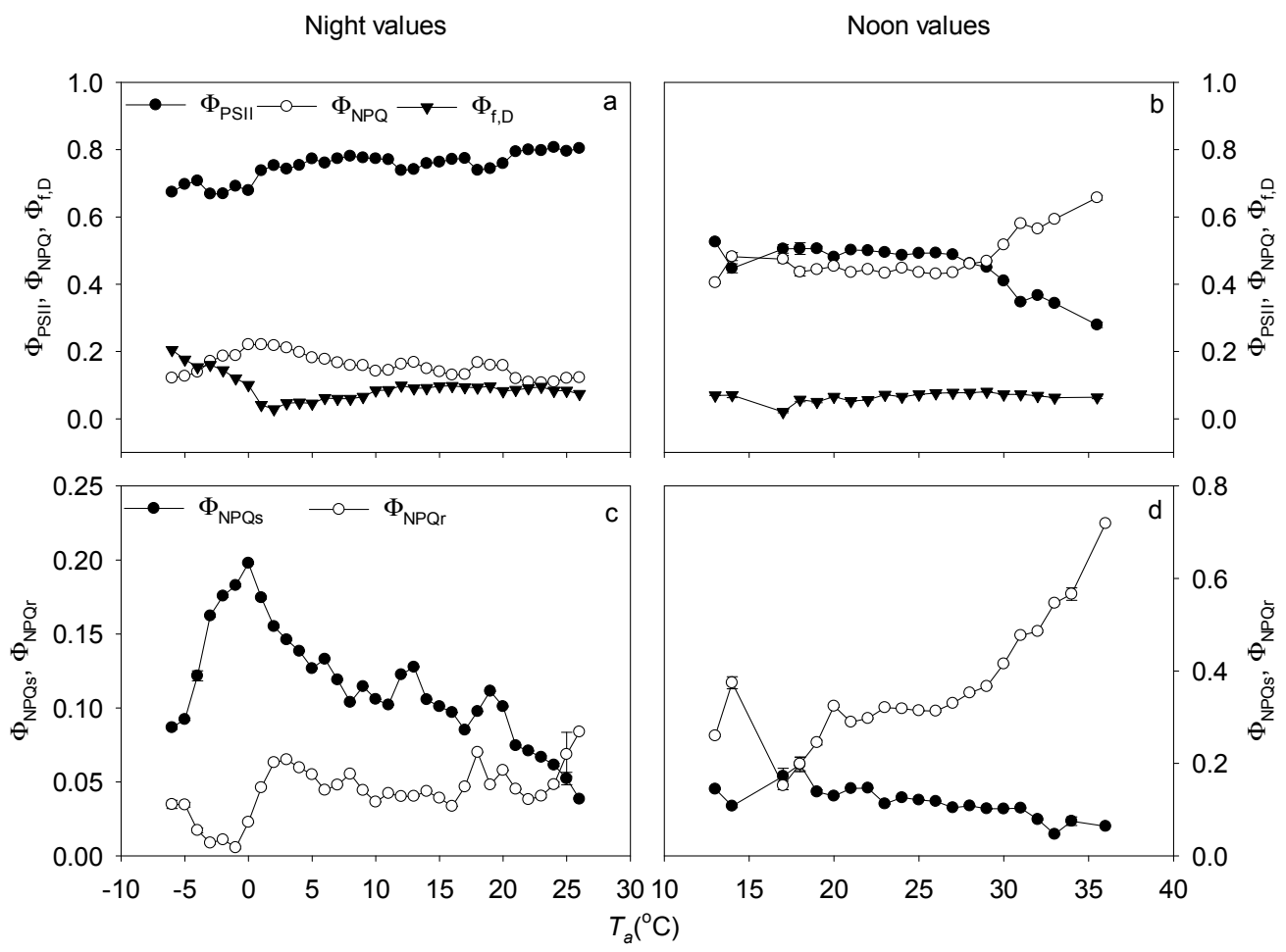

Figure 6. Actual quantum yield of PSII photochemistry $\left(\Phi_{\mathrm{PSII}}\right)$, regulated thermal energy loss $\left(\Phi_{\mathrm{NPQ}}\right)$, non-regulated energy loss $\left(\Phi_{\mathrm{f}, \mathrm{D}}\right)$, sustained and rapidly reversible thermal dissipation $\left(\Phi_{\mathrm{NPQs}}\right.$ and $\left.\Phi_{\mathrm{NPQr}}\right)$ as a function of air temperature $\left(T_{a}\right)$ at night $\left(P A R<5 \mu \mathrm{moL} \cdot \mathrm{m}^{-2} \cdot \mathrm{s}^{-1} ;(\mathbf{a}, \mathbf{c})\right)$ and at noon $\left(P A R \geq 1000 \mu \mathrm{moL} \cdot \mathrm{m}^{-2} \cdot \mathrm{s}^{-1} ;(\mathbf{b}, \mathbf{d})\right)$, respectively, during the 2012 growing season. Data points of energy partitioning represent bin-averaged values. Here, the bins are set at $1{ }^{\circ} \mathrm{C}$ increments of $T_{a}$ with a minimal sample size of six values. The error bars denote standard error.

\subsection{Seasonl Dynamics of Daily $F_{v} / F_{m}$}

Depressions in $\mathrm{F}_{v} / \mathrm{F}_{m}$ were identified at different levels throughout the growing season (Figure 7). Minor stress in Salix psammophila was recorded on April 25 under low temperatures and intense solar radiation $\left(\mathrm{F}_{v} / \mathrm{F}_{m}=0.72\right)$ and severe stress on 30 June to 4 July under intense solar radiation (0.14-0.52) and 5 October under low temperatures and intense solar radiation ( 0.6; Figures 2 and 7). Parameter $\mathrm{F}_{v} / \mathrm{F}_{m}$ recovered much more slowly in autumn, taking several more days, than in spring or summer, when temperatures were low at night. High resolution monitoring described the details of the photosynthetic depression dynamic with the fluctuation of environmental factors.

Diurnal dynamic of energy partitioning components $\left(\Phi_{\mathrm{PSII}}, \Phi_{\mathrm{NPQ}}, \Phi_{\mathrm{f}, \mathrm{D}}\right)$, along with temperature and PAR in three typical photoinhibition periods, are presented in Figure 8. The sudden acceleration of PAR (Figure $8 \mathrm{a}$ ), a combination of high temperature and high PAR (Figure $8 \mathbf{b}$ ), and low temperature 
(Figure 8c) would cause long lasting photoinhibition. Specifically, at the end of June (Figure 8a), continuous extreme high PAR (exceeded $1500 \mu \mathrm{moL} \cdot \mathrm{m}^{-2} \cdot \mathrm{s}^{-1}$ ) along with high temperature (around $30{ }^{\circ} \mathrm{C}$ ) after a few cloudy days resulted in severe and sustaining depression in $\Phi_{\mathrm{PSII}}$ (below 0.5). In late July (Figure 8b), relatively high PAR (exceeded $1200 \mu \mathrm{moL} \cdot \mathrm{m}^{-2} \cdot \mathrm{s}^{-1}$ ) and high temperature caused minor photoinhibition, with $\Phi_{\mathrm{PSII}}$ being around 0.7 for several days (Figure $8 \mathrm{~b}$ ). At the end of the growing season (Figure $8 \mathrm{c}$ ), the low temperature $\left(\sim 0{ }^{\circ} \mathrm{C}\right)$ led to moderate photoinhibition, with PSII being around 0.6 .

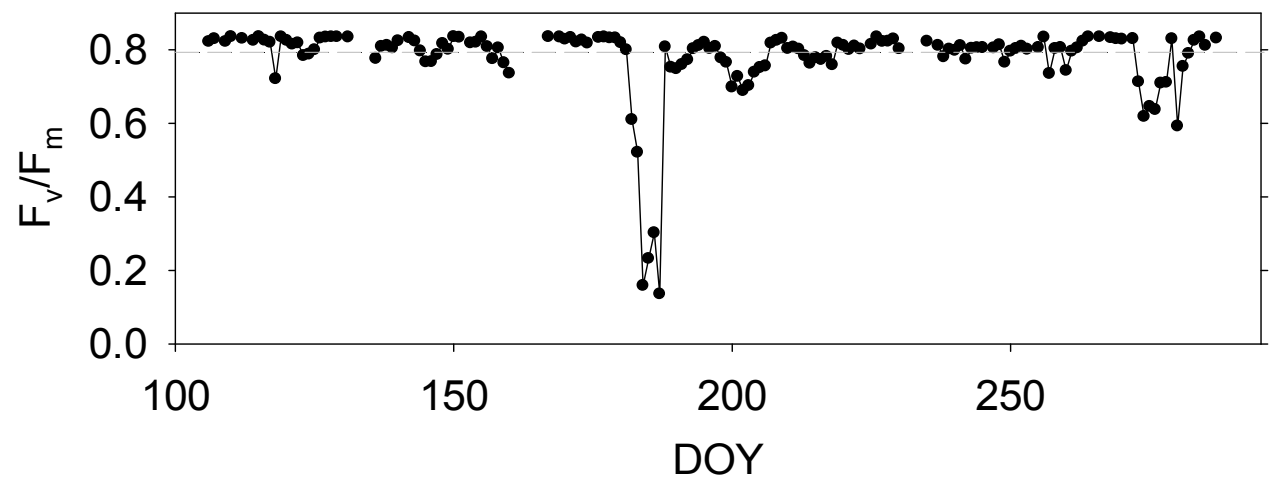

Figure 7. Seasonal variation of daily maximal quantum yield of PSII photochemistry $\left(\mathrm{F}_{v} / \mathrm{F}_{m}\right)$ in Salix psammophila during 2012 growing season.

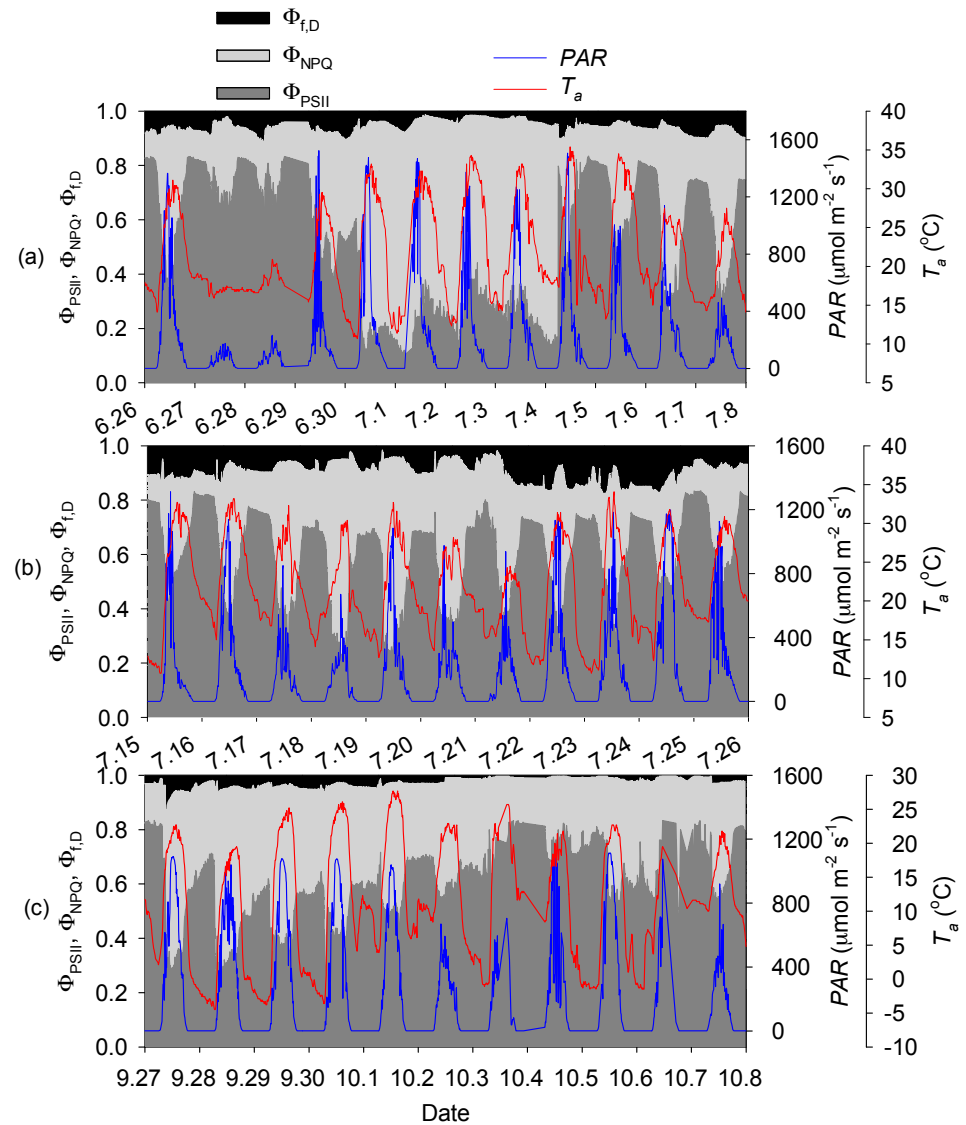

Figure 8. Dynamics of quantum yield of actual PSII photochemistry $\left(\Phi_{\mathrm{PSII}}\right)$, regulated energy loss $\left(\Phi_{\mathrm{NPQ}}\right)$, non-regulated energy loss $\left(\Phi_{\mathrm{f}, \mathrm{D}}\right)$ before, during, and after three typical photoinhibition periods in the growing season. Three typical photoinhibition periods are (a) 30 June-4 July, (b) 17 July-23 July, and (c) 28 September-3 October. 


\section{Discussion}

\subsection{Effect of Abiotic Factors on $F_{v} / F_{m}$}

As an indicator of the photochemical response to stress and overall plant health status [7,54], $\mathrm{F}_{v} / \mathrm{F}_{m}$ has been shown to have an optimal range between 0.75 and 0.85 , decreasing whenever plants are under stress. Some studies had reported a decrease in $\mathrm{F}_{v} / \mathrm{F}_{m}$ under water-deficit conditions $[55,56]$. However, reductions in $\mathrm{F}_{v} / \mathrm{F}_{m}$ at low $S W C$ and high $V P D$ were not readily discernible from our field measurements (Figure 9c,d), consistent with the previous studies [57,58]. The discrepancies in these studies could be attributed to the different growing conditions of the plants. Plants in favorable soil water conditions are generally more sensitive to drought, while Salix psammophila has a long-term acclimation to dry conditions in arid land. In contrast, severe stress was found to occur in non-water-limited conditions, i.e., SWC > 14\%. This particular condition may have developed because rain was distributed uniformly throughout the growing season (Figure $2 \mathrm{~d}$ ). Furthermore, the apparent negative correlation between $\mathrm{F}_{v} / \mathrm{F}_{m}$ and $T_{a}$ and maximum $P A R$, when $\mathrm{F}_{v} / \mathrm{F}_{m}<0.75$, provides some preliminary evidence of the photo-impairment in Salix psammophila due to extreme temperatures and PAR. Our results are consistent with those reported in previous studies for Salix psammophila growing in Inner Mongolia, China [45].
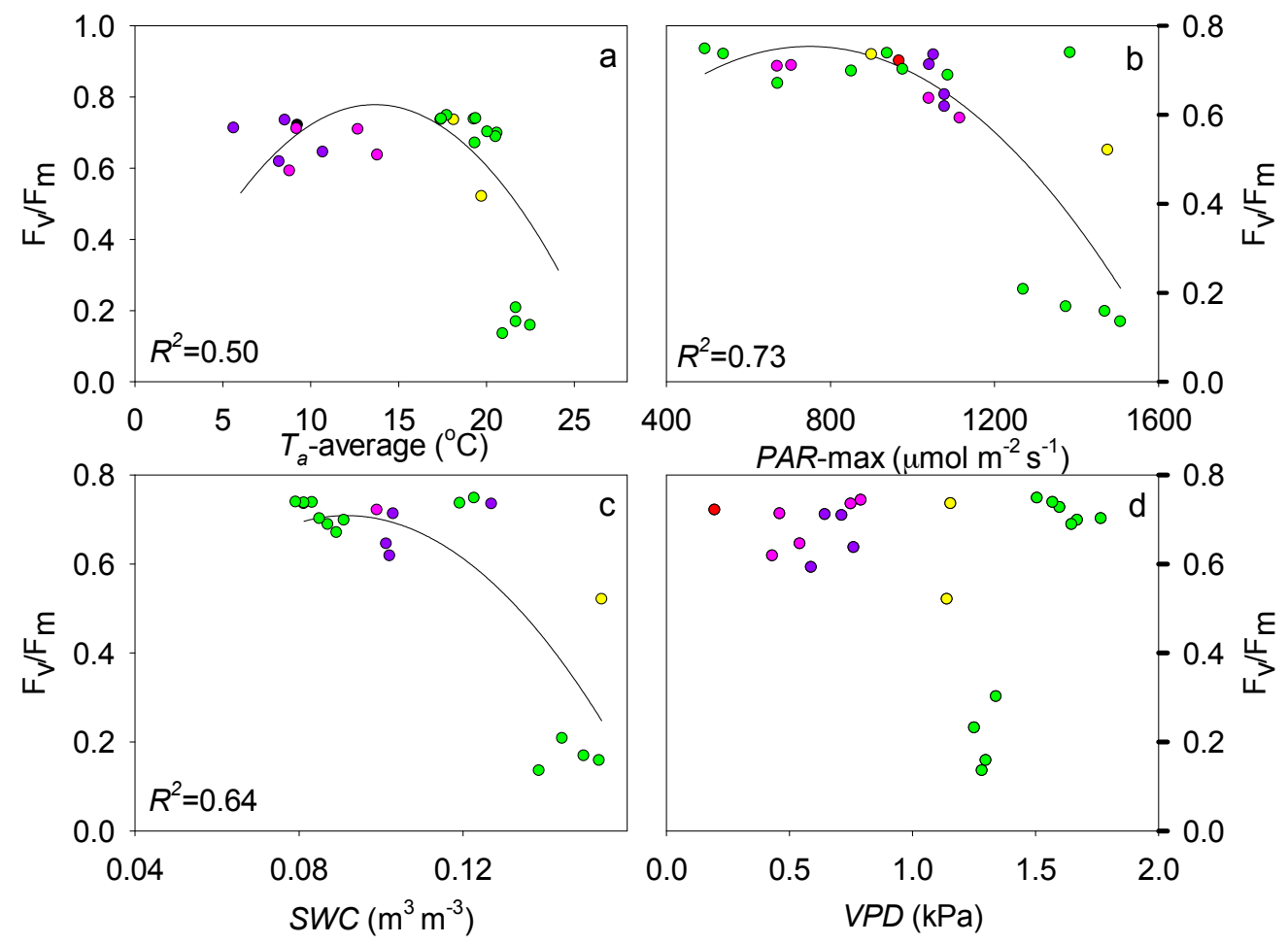

Figure 9. Maximal quantum yield of PSII photochemistry in Salix psammophila as a function of daily mean air temperature $\left(T_{a}, R^{2}=0.60,(\mathbf{a})\right)$, daily maximal photosynthetically active radiation (PAR, $\left.R^{2}=0.73,(\mathbf{b})\right)$, soil water content $\left(S W C, R^{2}=0.65,(\mathbf{c})\right)$, and vapor pressure deficit $(V P D,(\mathbf{d}))$ during the 2012 growing season. Data points are those with $\mathrm{F}_{v} / \mathrm{F}_{m}<0.75$, where photoinhibition occurred.

\subsection{Energy Partitioning in Response to Low Temperatures}

Under extreme sub-zero temperatures, high photoinhibition characterized by a low photosynthetic efficiency and quenching was shown to occur in over-wintering coniferophytes [59,60]. These species have cold-hardening mechanisms conferring freeze tolerance with specific physiological and morphological features $[59,61]$. Similar to many other temperate regions, occasional short chilling episodes are typical for our study area. Our ChlF-data consistently indicated a decrease in 
photochemical efficiency at low temperatures. Salix psammophila generally exhibited elevated $\Phi_{\mathrm{f}, \mathrm{D}}$ and low $\Phi_{\mathrm{NPQ}}$ (Figure 6a), which is explained by a reduction in the repair of RC's [62], leading to a suppression in $\Phi_{\mathrm{PSII}}$ at night (Figure 6a). A possible further explanation for this would be that the inhibition of antioxidant enzyme activity by chilling may have led to the production of ROS, which may have imparted serious oxidative damage to the photosynthetic apparatus [63]. A decrease in temperature was proved to reduce the activity of Calvin-Benson cycle enzymes, which would reduce PSII light utilization through reducing the NADPH demands and causing the subsequent accumulation of reductants [15]. A similar result was found in a high latitude area, where freezing impaired dark reactions and inhibited the capacity of light reactions to dissipate excess energy as heat [64]. Elevated $\Phi_{\mathrm{f}, \mathrm{D}}$ and low $\Phi_{\mathrm{NPQ}}$ in cold air conditions suggest an inappropriate level of photoprotection, resulting in photodamage. Moreover, $\Phi_{\mathrm{NPQ}}$ was mainly functional in cold conditions $<0{ }^{\circ} \mathrm{C}$, where Salix psammophila had a limited protection against upregulated $\Phi_{\mathrm{NPQ}}$. Low photochemical efficiency was also observed in shrubs in the Mediterranean region, when temperatures fell below $10{ }^{\circ} \mathrm{C}$ [65].

Given the same temperatures and similar solar radiation intensities during the cold months, May had higher $\Phi_{\mathrm{NPQ}}$ and lower $\Phi_{\mathrm{f}, \mathrm{D}}$ than in September, and a higher photochemical efficiency (Figures $1 \mathrm{a}$ and $2 \mathrm{~b}$ ). This can be explained by a heightened sensitivity in senescent leaves during the late growing season. In addition, reversible thermal dissipation was degenerative in September and sustained thermal dissipation increased when PAR was high (Figure 5), indicating a reduction in NPQ by variable thermal dissipation in autumn [3,21]. Increased $\Phi_{\mathrm{f}, \mathrm{D}}$ combined with decreased photoprotection instituted the point that physiologically-induced vulnerability in autumn reduced Salix psammophila's tolerance to stress.

\subsection{Energy Partitioning in Response to High Temperatures}

PSII is very sensitive to light fluctuations. High temperatures have the potential to accelerate photoinhibition, even photodamage in plants, by inducing an imbalance between light energy absorption and partitioning, while light-induced photodamage to PSII and the repair of photodamaged PSII occur simultaneously [15]. While in this study, although high radiation combined with high temperature resulted in a minor photoinhibition in Salix psammophila (Figure 8b), the photodamage was not caused by enhanced temperature $\left(\Phi_{\mathrm{f}, \mathrm{D}}\right.$ 's were persistently low, Figure $\left.6 \mathrm{~b}\right)$. Correspondingly, $\Phi_{\mathrm{NPQ}}$, especially the reversible form of thermal dissipation, was the major energy loss under high temperatures when air temperatures were greater than $30^{\circ} \mathrm{C}$. Under these conditions, the proportion of NPQ exceeded photochemical quenching (Figure $6 \mathrm{~b}$ ). This harmless $\Delta \mathrm{pH}$-dependent quenching associated with the conversion of violaxanthin via antheraxanthin to zeaxanthin decreases the rate of PSII photodamage under intense radiation [66-68]. NPQ regulation of energy partitioning within PSII plays an important role in the acclimation mechanism to withstand high temperatures in existing field conditions. Similar findings were obtained for an endangered Cistaceae spp., i.e., Tuberaria major, which had the ability to protect itself from irreversible photodamage under high temperatures, even under soil water shortage [37]. In general, net photosynthesis in Salix psammophila was not measurable when leaf temperatures exceeded $40{ }^{\circ} \mathrm{C}$ [45]. The current results are consistent with those presented in a previous study [40], which demonstrated that stress under moderately-high temperatures causes a partial inhibition in PSII. In the future, with global warming, more intense, more frequent, and longer heat waves are anticipated [69], which poses a considerable threat to the survival of the species in the Mu Us desert.

\subsection{Energy Partitioning in Response to Solar Radiation}

Salix psammophila provides morphological photoprotection by possessing lanceolate and revolute leaves that reduce light interception, limiting the likelihood that events of high insolation will exceed the physiological tolerance of the species [70]. Exposure to high solar radiation, energy partitioning by Salix psammophila was shown to vary over the different seasons. Results from this study showed 
a rapid decrease in $\Phi_{\mathrm{PSII}}$, a rapid increase in $\Phi_{\mathrm{NPQ}}$, and the predominance of $\Phi_{\mathrm{NPQ}}$ under moderate solar radiation intensity (below $1200 \mu \mathrm{moL} \cdot \mathrm{m}^{-2} \cdot \mathrm{s}^{-1}$; Figure $4 \mathrm{a}, \mathrm{b}$ ), suggesting that Salix psammophila was capable of acclimating to typical summer conditions by NPQ of reversible thermal dissipation (Figure 5a). Meanwhile, $\Phi_{\mathrm{NPQr}}$ played a dominant role in excess light energy dissipation, showing a strong xanthophyll-cycle regulation. High $P A R>1200 \mu \mathrm{mol} \cdot \mathrm{m}^{-2} \cdot \mathrm{s}^{-1}$, led to a more excessive thermal beyond self-regulation ability, disabling acclimation to high summer sunlight loading, yielding to a severe suppression in $\mathrm{F}_{v} / \mathrm{F}_{m}$ (Figure $9 \mathrm{~b}$ ). Many studies have reported PSII has an efficient and dynamic repair machinery where damaged PSII proteins (D1) are replaced with newly synthesized proteins [71-73]. While under extreme intense radiation, PSI would be damaged when the electron flow from PSII exceeds the capacity of PSI electron acceptors. PSI lacks efficient repair with a characteristic of low recovery [74]. The damaged PSI impaired PSII function by limiting electron transport between PSII and the Calvin-Benson cycle. Similar results were reported for full-sunlight-grown Arabidopsis thaliana with a higher chlorophyll content, where pronounced photo-oxidative and PSII-activity losses were detected. Additionally, during the late growing season, weakened NPQ-associated protection, indicated by a decrease in $\Phi_{\mathrm{NPQr}}$, meant that more excess light energy dissipated via the $\Phi_{\mathrm{f}, \mathrm{D}}$ form. This result supports our hypothesis that extreme high solar irradiation is an important stress factor affecting the afforestation quality of Salix psammophila, which also increases the sensitivity of Salix psammophila to biotic and abiotic stresses (e.g., senescence during the latter part of the growing season and low temperatures) at the level of gene expression [75].

\section{Conclusions}

ChlF-associated parameters $\mathrm{F}_{\mathcal{v}} / \mathrm{F}_{m}, \Phi_{\mathrm{NPQ}}, \Phi_{\mathrm{f}, \mathrm{D}}$, and NPQ are appropriate indicators to reflect environmentally-invoked stress in Salix psammophila. There exist different energy partitioning mechanisms in responding to different environmental stresses. Mechanisms of non-photochemical regulation explained the physiological plasticity of seasonal acclimation observed in Salix psammophila. Plants had a higher photochemical efficiency under moderate PAR and air temperature and allocated more energy to non-photochemical dissipation pathways. In extremely high PAR or in a cold temperature, more energy was dissipated by way of $\Phi_{\mathrm{NPQ}}$ and $\Phi_{\mathrm{f}, \mathrm{D}}$, leading to non-reversible photoinhibition. In high temperatures $\left(>30^{\circ} \mathrm{C}\right)$, but moderate radiation $\left(<1200 \mu \mathrm{moL} \cdot \mathrm{m}^{-2} \cdot \mathrm{s}^{-1}\right)$, the plants dissipated the energy more readily through $\Phi_{\mathrm{NPQ}}$, showing a strong tolerance. Given the more frequent extreme weather events projected for northwest China under global change, large plantations of Salix psammophila in the region are at an extreme risk of declining in the near future.

Author Contributions: T.Z., J.W., Y.T., and X.J. conceived and designed the experiment; Y.W., Y.B., J.M, and M.Z. collected data; Y.H. analysed the data and wrote the initial draft of the manuscript; C.P.-A.B. provided conceptual and editorial advice and re-wrote significant parts of the manuscript.

Acknowledgments: We acknowledge the support obtained from the National Key Research and Development Program of China (No. 2016YFC0500905), National Natural Science Foundation of China (NSFC) (No. 31670710 and 31670708) and Special Funds for Scientific and technological innovation ability construction of BAAFS (No. KJCX20170301). We thank M.Z. and Y.W. for their assistance with the field work. The U.S.-China Carbon Consortium (USCCC) supported this work by way of helpful discussion and exchange of ideas. We greatly appreciate the valuable comments from all anonymous reviewers of this manuscript.

Conflicts of Interest: The authors have declared that no competing interests exist.

$\begin{array}{ll}\text { Abbreviations } \\ \text { ChlF } & \text { Chlorophyll } a \text { Flouresence } \\ \text { PSII } & \text { Photosystem II } \\ \text { LHCII } & \text { Light-harvesting complex II } \\ \text { RC } & \text { Reaction center } \\ \text { PsbS } & \text { Photoprotective protein } \\ \text { ROS } & \text { Reactive oxygen species } \\ \Delta \mathrm{pH} & \text { Transthylakoid pH gradient }\end{array}$




$\begin{array}{ll}\mathrm{F}_{t} & \text { ChlF at any time } \\ \mathrm{F}_{m}{ }^{\prime} & \text { Maximal ChlF in light } \\ \mathrm{F}_{m} & \text { Maximal ChlF in dark } \\ \mathrm{F}_{o} & \text { Original ChlF } \\ \mathrm{F}_{m R} & \text { Reference maximal fluorescence } \\ \mathrm{F}_{v} & \text { Variable fluorescence } \\ \mathrm{F}_{v} / \mathrm{F}_{m} & \text { Maximal quantum yield of PSII photochemistry } \\ \mathrm{F}_{v}{ }^{\prime} / \mathrm{F}_{m}{ }^{\prime} & \text { Effective photochemical efficiency } \\ \mathrm{NPQ} & \text { Non-photochemical quenching } \\ \Phi_{\mathrm{PSI}} & \text { Actual quantum yield of PSII photochemistry } \\ \Phi_{\mathrm{NPQ}} & \text { Regulated thermal energy loss } \\ \Phi_{\mathrm{f}, \mathrm{D}} & \text { Non-regulated thermal energy loss } \\ \Phi_{\mathrm{NPQs}} & \text { Sustained thermal dissipation } \\ \Phi_{\mathrm{NPQr}} & \text { Rapidly reversible thermal dissipation } \\ P A R & \text { Photosynthetically active radiation } \\ P A R-\mathrm{max} & \text { Maximal PAR } \\ V P D & \text { Vapor pressure Deficit } \\ T_{a} & \text { Air temperature } \\ S W C & \text { Soil water content }\end{array}$

\section{References}

1. Oquist, G.; Huner, N.P. Photosynthesis of overwintering evergreen plants. Annu. Rev. Plant Biol. 2003, 54, 329-355. [CrossRef] [PubMed]

2. Baker, N.R. Chlorophyll fluorescence: A probe of photosynthesis in vivo. Annu. Rev. Plant Biol. 2008, 59, 89-113. [CrossRef] [PubMed]

3. Porcar-Castell, A.; Juurola, E.; Ensminger, I.; Berninger, F.; Hari, P.; Nikinmaa, E. Seasonal acclimation of photosystem II in Pinus sylvestris. II. Using the rate constants of sustained thermal energy dissipation and photochemistry to study the effect of the light environment. Tree Physiol. 2008, 28, 1483-1491. [CrossRef] [PubMed]

4. Howarth, J.F.; Durako, M.J. Diurnal variation in chlorophyll fluorescence of Thalassia testudinum seedlings in response to controlled salinity and light conditions. Mar. Biol. 2013, 160, 591-605. [CrossRef]

5. Haque, M.S.; Kjaer, K.H.; Rosenqvist, E.; Sharma, D.K.; Ottosen, C.O. Heat stress and recovery of photosystem II efficiency in wheat (Triticum aestivum L.) cultivars acclimated to different growth temperatures. Environ. Exp. Bot. 2014, 99, 1-8. [CrossRef]

6. Janka, E.; Körner, O.; Rosenqvist, E.; Ottosen, C.-O. Using the quantum yields of photosystem II and the rate of net photosynthesis to monitor high irradiance and temperature stress in chrysanthemum (Dendranthema grandiflora). Plant Physiol. Biochem. 2015, 90, 14-22. [CrossRef] [PubMed]

7. Zunzunegui, M.; Barradas, M.C.D.; Ain-Lhout, F.; Alvarez-Cansino, L.; Esquivias, M.; Novo, F.G. Seasonal physiological plasticity and recovery capacity after summer stress in Mediterranean scrub communities. Plant Ecol. 2011, 212, 127-142. [CrossRef]

8. Wong, S.L.; Chen, C.W.; Huang, H.W.; Weng, J.H. Using combined measurements of gas exchange and chlorophyll fluorescence to investigate the photosynthetic light responses of plant species adapted to different light regimes. Photosynthetica 2012, 50, 206-214. [CrossRef]

9. Oukarroum, A.; Strasser, R.J.; Schansker, G. Heat stress and the photosynthetic electron transport chain of the lichen Parmelina tiliacea (Hoffm.) Ach. in the dry and the wet state: Differences and similarities with the heat stress response of higher plants. Photosynth. Res. 2012, 111, 303-314. [CrossRef] [PubMed]

10. Melkonian, J.; Owens, T.G.; Wolfe, D.W. Gas exchange and co-regulation of photochemical and nonphotochemical quenching in bean during chilling at ambient and elevated carbon dioxide. Photosynth. Res. 2004, 79, 71-82. [CrossRef] [PubMed]

11. Cheng, T.; Chen, J.; Abd_Allah, E.; Wang, P.; Wang, G.; Hu, X.; Shi, J. Quantitative proteomics analysis reveals that S-nitrosoglutathione reductase (GSNOR) and nitric oxide signaling enhance poplar defense against chilling stress. Planta 2015, 242, 1361-1390. [CrossRef] [PubMed] 
12. Lavaud, J.; Rousseau, B.; Etienne, A.L. In diatoms, a transthylakoid proton gradient alone is not sufficient to induce a non-photochemical fluorescence quenching. FEBS Lett. 2002, 523, 163-166. [CrossRef]

13. Ruban, A.V.; Berera, R.; Ilioaia, C.; Van Stokkum, I.H.; Kennis, J.T.; Pascal, A.A.; Van Amerongen, H.; Robert, B.; Horton, P.; Van Grondelle, R. Identification of a mechanism of photoprotective energy dissipation in higher plants. Nature 2007, 450, 575-578. [CrossRef] [PubMed]

14. Chen, J.W.; Kuang, S.B.; Long, G.Q.; Yang, S.C.; Meng, Z.G.; Li, L.G.; Chen, Z.J.; Zhang, G.H. Photosynthesis, light energy partitioning, and photoprotection in the shade-demanding species Panax notoginseng under high and low level of growth irradiance. Funct. Plant Biol. 2016, 43, 479-491. [CrossRef]

15. Yamori, W. Photosynthetic response to fluctuating environments and photoprotective strategies under abiotic stress. J. Plant Res. 2016, 129, 379-395. [CrossRef] [PubMed]

16. Hallik, L.; Niinemets, Ü.; Kull, O. Photosynthetic acclimation to light in woody and herbaceous species: A comparison of leaf structure, pigment content and chlorophyll fluorescence characteristics measured in the field. Plant Biol. 2012, 14, 88-99. [CrossRef] [PubMed]

17. Hendrickson, L.; Furbank, R.T.; Chow, W.S. A simple alternative approach to assessing the fate of absorbed light energy using chlorophyll fluorescence. Photosynth. Res. 2004, 82, 73-81. [CrossRef] [PubMed]

18. Klughammer, C.; Schreiber, U. Complementary PS II quantum yields calculated from simple fluorescence parameters measured by PAM fluorometry and the Saturation Pulse method. PAM Appl. Notes 2008, 1, 201-247.

19. Losciale, P.; Chow, W.S.; Corelli Grappadelli, L. Modulating the light environment with the peach 'asymmetric orchard': Effects on gas exchange performances, photoprotection, and photoinhibition. J. Exp. Bot. 2010, 61, 1177-1192. [CrossRef] [PubMed]

20. Kramer, D.M.; Johnson, G.; Kiirats, O.; Edwards, G.E. New fluorescence parameters for the determination of QA redox state and excitation energy fluxes. Photosynth. Res. 2004, 79, 209-218. [CrossRef] [PubMed]

21. Demmig-Adams, B.; Adams, W.W. Photoprotection in an Ecological Context: The Remarkable Complexity of Thermal Energy Dissipation. New Phytol. 2006, 172, 11-21. [CrossRef] [PubMed]

22. Müller, P.; Li, X.-P.; Niyogi, K.K. Non-photochemical quenching. A response to excess light energy. Plant Physiol. 2001, 125, 1558-1566. [CrossRef] [PubMed]

23. Verhoeven, A.S.; Adams, W.W.; Demmig-Adams, B. Two forms of sustained xanthophyll cycle-dependent energy dissipation in overwintering Euonymus kiautschovicus. Plant Cell Environ. 1998, 21, 893-903. [CrossRef]

24. Lloyd, J. Soil Temperature and Intermittent Frost Modulate the Rate of Recovery of Photosynthesis in Scots Pine under Simulated Spring Conditions. New Phytol. 2008, 177, 428.

25. Busch, F.; Hüner, N.P.; Ensminger, I. Increased air temperature during simulated autumn conditions does not increase photosynthetic carbon gain but affects the dissipation of excess energy in seedlings of the evergreen conifer Jack pine. Plant Physiol. 2007, 143, 1242-1251. [CrossRef] [PubMed]

26. Cai, M.; Ren, R. Meridional and downward propagation of atmospheric circulation anomalies. Part I: Northern Hemisphere cold season variability. J. Atmos. Sci. 2007, 64, 1880-1901. [CrossRef]

27. Chen, S.; Wang, J.; Xing, X.; Guo, J. Relationship between Abnormal OLR over Qinghai-Tibet Plateau and Air Temperature in Arid Region of Northwest China. J. Arid Meteorol. 2011, 3, 276-282.

28. Chen, S.; Zheng, Y.; Lou, W.; Guo, Y. Changes in the First Frost Date from 1961 to 2009 in Northwest China. Resour. Sci. 2013, 35, 165-172.

29. Saxe, H.; Ellsworth, D.S.; Heath, J. Tansley Review No. 98 Tree and Forest Functioning in an Enriched $\mathrm{CO}_{2}$ Atmosphere. New Phytol. 1998, 139, 395-436. [CrossRef]

30. Sicher, R.C.; Bunce, J.A. Relationship of photosynthetic acclimation to changes of Rubisco activity in field-grown winter wheat and barley during growth in elevated carbon dioxide. Photosynth. Res. 1997, 52, 27-38. [CrossRef]

31. Bunce, J.A. Direct and acclimatory responses of stomatal conductance to elevated carbon dioxide in four herbaceous crop species in the field. Glob. Chang. Biol. 2001, 7, 323-331. [CrossRef]

32. Yamori, W.; Hikosaka, K.; Way, D.A. Temperature response of photosynthesis in C3, C4, and CAM plants: Temperature acclimation and temperature adaptation. Photosynth. Res. 2014, 119, 101-117. [CrossRef] [PubMed]

33. Zhang, S.B.; Hu, H.; Xu, K.; Li, Z.R.; Yang, Y.P. Flexible and reversible responses to different irradiance levels during photosynthetic acclimation of Cypripedium guttatum. J. Plant Physiol. 2007, 164, 611-620. [CrossRef] [PubMed] 
34. Dai, Y.; Shen, Z.; Liu, Y.; Wang, L.; Hannaway, D.; Lu, H. Effects of shade treatments on the photosynthetic capacity, chlorophyll fluorescence, and chlorophyll content of Tetrastigma hemsleyanum Diels et Gilg. Environ. Exp. Bot. 2009, 65, 177-182. [CrossRef]

35. Munson, S.M. Plant responses, climate pivot points, and trade-offs in water-limited ecosystems. Ecosphere 2013, 4, 1-15. [CrossRef]

36. Maphangwa, K.W.; Musil, C.F.; Raitt, L.; Zedda, L. Experimental climate warming decreases photosynthetic efficiency of lichens in an arid South African ecosystem. Oecologia 2012, 169, 257-268. [CrossRef] [PubMed]

37. Osório, M.L.; Osório, J.; Romano, A. Photosynthesis, energy partitioning, and metabolic adjustments of the endangered Cistaceae species Tuberaria major under high temperature and drought. Photosynthetica 2013, 51, 75-84. [CrossRef]

38. Tominaga, J.; Inafuku, S.; Coetzee, T.; Kawamitsu, Y. Diurnal regulation of photosynthesis in Jatropha curcas under drought during summer in a semi-arid region. Biomass Bioenergy 2014, 67, 279-287. [CrossRef]

39. Song, L.; Chow, W.S.; Sun, L.; Li, C.; Peng, C. Acclimation of photosystem II to high temperature in two Wedelia species from different geographical origins: Implications for biological invasions upon global warming. J. Exp. Bot. 2010, 61, 4087-4096. [CrossRef] [PubMed]

40. Sun, G.; Zeng, X.; Liu, X.; Zhao, P. Effects of moderate high-temperature stress on photosynthesis in three saplings of the constructive tree species of subtropical forest. Plant Cell Environ. 2007, 27, 1283-1290.

41. Sharkey, T.D. Effects of moderate heat stress on photosynthesis: Importance of thylakoid reactions, rubisco deactivation, reactive oxygen species, and thermotolerance provided by isoprene. Plant Cell Environ. 2005, 28, 269-277. [CrossRef]

42. Yamane, Y.; Kashino, Y.; Koike, H.; Satoh, K. Effects of high temperatures on the photosynthetic systems in spinach: Oxygen-evolving activities, fluorescence characteristics and the denaturation process. Photosynth. Res. 1998, 57, 51-59. [CrossRef]

43. Stasik, O.; Jones, H.G. Response of photosynthetic apparatus to moderate high temperature in contrasting wheat cultivars at different oxygen concentrations. J. Exp. Bot. 2007, 58, 2133-2143. [CrossRef] [PubMed]

44. Ort, D.R. Impacts of chilling temperatures on photosynthesis in warm-climate plants. Trends Plant Sci. 2001, 6, 36.

45. Jiang, G.; Zhu, G. Effects of natural high temperature and irradiatic on photosynthesis and related parameters in three arid sandy shrub species. Acta Phytoecol. Sin. 2000, 25, 525-531.

46. Chen, G.; Zhao, W. Age structure and dynamics of Salix psammophila branches in southern edge of the Mu Us Sandy Land. J. Desert Res. 2015, 35, 1520-1526.

47. Chen, X.; Duan, Z. Changes in soil physical and chemical properties during reversal of desertification in Yanchi County of Ningxia Hui autonomous region, China. Environ. Geol. 2009, 57, 975-985. [CrossRef]

48. Wang, B.; Zha, T.; Jia, X.; Wu, B.; Zhang, Y.; Qin, S. Soil moisture modifies the response of soil respiration to temperature in a desert shrub ecosystem. Biogeosciences 2014, 11, 259-268. [CrossRef]

49. Porcar-Castell, A. A high-resolution portrait of the annual dynamics of photochemical and non-photochemical quenching in needles of Pinus sylvestris. Physiol. Plant. 2011, 143, 139-153. [CrossRef] [PubMed]

50. Zha, T.S.; Wu, Y.J.; Jia, X.; Zhang, M.Y.; Bai, Y.J.; Liu, P.; Ma, J.Y.; Bourque, P.A.; Peltola, H. Diurnal response of effective quantum yield of PSII photochemistry to irradiance as an indicator of photosynthetic acclimation to stressed environments revealed in a xerophytic species. Ecol. Indicators 2017, 74, 191-197. [CrossRef]

51. Cailly, A.; Rizza, F.; Genty, B.; Harbinson, J. Fate of excitation at PS II in leaves. The non-photochemical side. In Proceedings of the 10th FESPP Meeting, Florence, Italy, 9-13 September 1996.

52. Mathur, S.; Agrawal, D.; Jajoo, A. Photosynthesis: Response to high temperature stress. J. Photchem. Photobiol. B Biol. 2014, 137, 116-126. [CrossRef] [PubMed]

53. Kornyeyev, D.; Hendrickson, L. Research note: Energy partitioning in photosystem II complexes subjected to photoinhibitory treatment. Funct. Plant Biol. 2007, 34, 214-220. [CrossRef]

54. Neveux, J.; Dupouy, C.; Blanchot, J.; Le Bouteiller, A.; Landry, M.R.; Brown, S.L. Diel dynamics of chlorophylls in high-nutrient, low-chlorophyll waters of the equatorial Pacific $\left(180^{\circ}\right)$ : Interactions of growth, grazing, physiological responses, and mixing. J. Geophys. Res. Oceans 2003, 108. [CrossRef]

55. Su, L.; Dai, Z.; Li, S.; Xin, H. A novel system for evaluating drought-cold tolerance of grapevines using chlorophyll fluorescence. BMC Plant Biol. 2015, 15, 1-12. [CrossRef] [PubMed]

56. Prieto, P.; Peñuelas, J.; Llusià, J.; Asensio, D.; Estiarte, M. Effects of long-term experimental night-time warming and drought on photosynthesis, $\mathrm{Fv} / \mathrm{Fm}$ and stomatal conductance in the dominant species of a Mediterranean shrubland. Acta Physiol. Plant. 2009, 31, 729-739. [CrossRef] 
57. Longenberger, P.S.; Smith, C.W.; Duke, S.E.; McMichael, B.L. Evaluation of chlorophyll fluorescence as a tool for the identification of drought tolerance in upland cotton. Euphytica 2009, 166, 25. [CrossRef]

58. Wang, Z.X.; Chen, L.; Ai, J.; Qin, H.Y.; Liu, Y.X.; Xu, P.L.; Jiao, Z.Q.; Zhao, Y.; Zhang, Q.T. Photosynthesis and activity of photosystem II in response to drought stress in Amur Grape (Vitis amurensis Rupr.). Photosynthetica 2012, 50, 189-196. [CrossRef]

59. Huner, N.P.A.; Öquist, G.; Sarhan, F. Energy balance and acclimation to light and cold. Trends Plant Sci. 1998, 3, 224-230. [CrossRef]

60. Sveshnikov, D.; Ensminger, I.; Ivanov, A.G.; Campbell, D.; Lloyd, J.; Funk, C.; Hüner, N.P.; Oquist, G. Excitation energy partitioning and quenching during cold acclimation in Scots pine. Tree Physiol. 2006, 26, 325. [CrossRef] [PubMed]

61. Hurry, V.M.; Strand, A.; Tobiaeson, M.; Gardestrom, P.; Oquist, G. Cold Hardening of Spring and Winter Wheat and Rape Results in Differential Effects on Growth, Carbon Metabolism, and Carbohydrate Content. Plant Physiol. 1995, 109, 697. [CrossRef] [PubMed]

62. Nath, K.; Jajoo, A.; Poudyal, R.S.; Timilsina, R.; Park, Y.S.; Aro, E.M.; Nam, H.G.; Lee, C.H. Towards a critical understanding of the photosystem II repair mechanism and its regulation during stress conditions. FEBS Lett. 2013, 587, 3372-3381. [CrossRef] [PubMed]

63. Li, X.; Gong, B.; Xu, K. Interaction of nitric oxide and polyamines involves antioxidants and physiological strategies against chilling-induced oxidative damage in Zingiber officinale Roscoe. Sci. Hortic. 2014, 170, 237-248. [CrossRef]

64. Lindfors, L.; Hölttä, T.; Lintunen, A.; Porcar-Castell, A.; Nikinmaa, E.; Juurola, E. Dynamics of leaf gas exchange, chlorophyll fluorescence and stem diameter changes during freezing and thawing of Scots pine seedlings. Tree Physiol. 2015, 35, 1314. [CrossRef] [PubMed]

65. Gulías, J.; Cifre, J.; Jonasson, S.; Medrano, H.; Flexas, J. Seasonal and inter-annual variations of gas exchange in thirteen woody species along a climatic gradient in the Mediterranean island of Mallorca. Flora 2009, 204, 169-181. [CrossRef]

66. Havaux, M.; Niyogi, K.K. The violaxanthin cycle protects plants from photooxidative damage by more than one mechanism. Proc. Natl. Acad. Sci. USA 1999, 96, 8762-8767. [CrossRef] [PubMed]

67. Li, X.P.; Müller-Moulé, P.; Gilmore, A.M.; Niyogi, K.K. PsbS-Dependent Enhancement of Feedback De-Excitation Protects Photosystem II from Photoinhibition. Proc. Natl. Acad. Sci. USA 2002, 99, 15222. [CrossRef] [PubMed]

68. Niyogi, K.K.; Li, X.P.; Rosenberg, V.; Jung, H.S. Is PsbS the site of non-photochemical quenching in photosynthesis? J. Exp. Bot. 2005, 56, 375-382. [CrossRef] [PubMed]

69. Song, L.Y.; Li, C.H.; Peng, S.L. Elevated $\mathrm{CO}_{2}$ increases energy-use efficiency of invasive wedelia trilobata over its indigenous congenger. Biol. Invasions 2010, 12, 1221-1230. [CrossRef]

70. Rapparini, F.; Neri, L.; Mihailova, G.; Petkova, S.; Georgieva, K. Growth irradiance affects the photoprotective mechanisms of the resurrection angiosperm Haberlea rhodopensis Friv. in response to desiccation and rehydration at morphological, physiological and biochemical levels. Environ. Exp. Bot. 2015, 113, 67-79. [CrossRef]

71. Aro, E.M.; Virgin, I.; Andersson, B. Photoinhibition of Photosystem II. Inactivation, protein damage and turnover. Biochim. Biophys. Acta Bioenerg. 1993, 1143, 113. [CrossRef]

72. Aro, E.M.; Suorsa, M.; Rokka, A.; Allahverdiyeva, Y.; Paakkarinen, V.; Saleem, A.; Battchikova, N.; Rintamäki, E. Dynamics of photosystem II: A proteomic approach to thylakoid protein complexes. J. Exp. Bot. 2005, 56, 347-356. [CrossRef] [PubMed]

73. Takahashi, S.; Badger, M.R. Photoprotection in plants: A new light on photosystem II damage. Trends Plant Sci. 2011, 16, 53-60. [CrossRef] [PubMed]

74. Kudoh, H.; Sonoike, K. Irreversible damage to photosystem I by chilling in the light: Cause of the degradation of chlorophyll after returning to normal growth temperature. Planta 2002, 215, 541-548. [CrossRef] [PubMed]

75. Ksas, B.; Becuwe, N.; Chevalier, A.; Havaux, M. Plant tolerance to excess light energy and photooxidative damage relies on plastoquinone biosynthesis. Sci. Rep. 2015, 5, 10919. [CrossRef] [PubMed]

(C) 2018 by the authors. Licensee MDPI, Basel, Switzerland. This article is an open access article distributed under the terms and conditions of the Creative Commons Attribution (CC BY) license (http://creativecommons.org/licenses/by/4.0/). 